\title{
Pleistocene coralline algal build-ups (coralligène de plateau) and associated bioclastic deposits in the sedimentary cover of Cutro marine terrace (Calabria, southern Italy)
}

\author{
R. NALIN ${ }^{1}$, D. BASSO${ }^{2} \&$ F. MASSARI ${ }^{1}$ \\ ${ }^{1}$ Dipartimento di Geologia, Paleontologia e Geofisica, Università di Padova, Via Giotto 1, \\ 35134, Padova, Italy (e-mail: ronald.nalin@unipd.it) \\ ${ }^{2}$ Dipartimento di Scienze Geologiche e Geotecnologie, Università di Milano Bicocca, \\ Piazza della Scienza 4, 20126 Milano, Italy
}

\begin{abstract}
Carbonate build-ups mainly constructed by encrusting coralline red algae are currently developing on Mediterranean soft bottoms, at depths ranging from $20 \mathrm{~m}$ to $160 \mathrm{~m}$. They are usually referred to as 'coralligène de plateau'. Few fossil examples of these bioconstructions have been described in the literature and their evolution in the context of a stratigraphic cycle has never been modelled in detail. Cutro marine terrace (Calabria, southern Italy) preserves mid-Pleistocene deposits assigned to Marine Isotope Stage (MIS) 7 or MIS 9. Extensive algal build-ups representing the deepest unit of the succession occur in the outer and central portion of the terrace, interpreted as the most distal setting from the palaeo-shoreline. Two studied sections, Vrica and Telegrafo, showed that the solid biogenic framework grew over a basal rhodolithic layer, which was stabilized by the binding activity and overgrowth of nongeniculate Corallinales (calcareous red algae). Therefore, these bioconstructions represent a rare fossil example of coralligène de plateau. At the Telegrafo section, Titanoderma pustulatum has been identified as the major rhodolith component. The build-ups are dominated by $T$. pustulatum, associated mainly with Mesophyllum spp. and locally with Lithophyllum stictaeforme. Rhodalgal bioclastic deposits are found in lateral contact with the build-ups. The two facies developed together under a hydrodynamic regime where phases of sedimentation from storm-driven currents alternated with phases of calm conditions. They were deposited during a single stratigraphic cycle beginning with the generation of a ravinement surface during the transgressive systems tract (TST) and ending with the burial of the coralligène by wellsorted shoreface bioclastic sands. Optimal and extensive growth of the coralligene took place during the highstand systems tract (HST).
\end{abstract}

The Mediterranean Sea represents an excellent example of a temperate domain where carbonate sediments of the Heterozoan Association are produced and deposited widely (James 1997). Pérès \& Picard (1964) offered a synopsis of recent Mediterranean biocoenoses, aiming at the definition of characteristic subenvironments and related sedimentary products. With the term 'coralligène de plateau', also translated as 'coralligenous bank' (Pérès 1967, 1982), they referred to a rigid framework built mainly by encrusting coralline red algae, developing on Mediterranean soft bottoms at depths ranging from $20 \mathrm{~m}$ to $160 \mathrm{~m}$. This variable distribution is a function of light penetration, with deeper settlements occurring in the highly transparent waters of the Eastern Mediterranean Sea but average optimal growth-depth between $40 \mathrm{~m}$ and $60 \mathrm{~m}$. Secondary framework builders, such as bryozoans, encrusting foraminifers and serpulids, may contribute to the growth of the build-up.
Apart from its palaeoecological significance, the study of the coralligène de plateau is very attractive for several reasons. First, the ability to colonize mobile substrates is a key element which distinguishes the coralligène de plateau from other types of coralline algal frameworks growing in shallower settings, such as algal ridges, algal cup reefs and trottoirs, or the coralligène installed on rocky substrate (Laborel 1961). Secondly, the coralligène de plateau is characterized usually by an open algal framework infilled with fine interstitial sediment, suggesting growth in quiet environmental conditions; nevertheless, it is often found in lateral contact with coarse mainly bioclastic deposits, with bedforms and sedimentary structures indicative of current activity. This paradox raises the question as to what type of hydrodynamic regime may account for the coexistence of such apparently contrasting features. Finally, very few fossil examples have been interpreted as 
coralligène de plateau (Bosence \& Pedley 1982; Carannante \& Simone 1996; Rasser 2000; Nelson et al. 2001; Rasser \& Piller 2004) and most are Tertiary analogues that formed under very different climatic and palaeo-biological conditions than those of the modern Mediterranean. Moreover, despite its relatively well-documented modern occurrence in the Mediterranean Sea, knowledge of the genesis and structure of this temperatewater bioconstruction is rather poor.

The study of mid-Pleistocene algal build-ups of the Crotone Peninsula (southern Italy), which appear to be a manifest example of coralligène de plateau and associated bioclastic deposits, offered the possibility to gain further insights into the above-mentioned topics. The observations were framed in a simple sequence-stratigraphic scheme, with the aim of modelling the response of these peculiar sedimentary products to a single transgressive-regressive cycle.

\section{Study area}

The Crotone peninsula (Calabria, southern Italy) is characterized by the presence of a flight of well-developed marine terraces (Zecchin et al. 2004), originating from the interplay of glacioeustatic sea-level fluctuations and continuous uplift of the area. The highest and oldest terrace, named Cutro terrace, preserves a thin (max. $15 \mathrm{~m}$ thick) sedimentary cover lying unconformably on a Plio-Pleistocene substrate of outer shelf to slope marly clays (Massari et al. 2002), named Cutro Marly Clay by Roda (1964). The deposits of Cutro terrace are mid-Pleistocene in age and have been assigned to MIS 7 (Gliozzi 1987) or to MIS 9 (Palmentola et al. 1990). Detailed observation of the facies distribution of the deposits (Gliozzi 1987; Zecchin et al. 2004) revealed the presence of extensive algal build-ups, which represent the deepest-water unit of the succession. The buildups are found prevalently in the outer and central portions of the terrace, therefore indicating growth in the most distal settings with respect to the palaeo-shoreline.

In order to investigate the coralline algal bioconstructions and associated deposits, two sections were selected in the outer portion of the terrace (Fig. 1), one on the external margin (Vrica) and the other on an abandoned quarry (Telegrafo).

\section{Methods}

At the Telegrafo section (UTM coordinates: 685 $050,4316134)$ the walls of the quarry are orientated in several directions, allowing a threedimensional view of the build-up architecture. For taxonomic and palaeoecological characterization of coralline algae, two bioconstructions $(4.5 \mathrm{~m}$ and $1.3 \mathrm{~m}$ high) were selected and sampled every $30 \mathrm{~cm}$ along a vertical transect, collecting 15 and 5 samples, respectively. Thin sections were obtained from these samples. The basal contact with the Cutro Marly Clay substrate corresponds with the floor of the quarry; therefore, even if the contact could not actually be seen, the first sample of the transects (taken at the base of the section) is inferred to be only a few centimetres above the contact. Four additional samples were taken at the contact between algal build-ups and laterally occurring bioclastic deposits and 14 samples were taken within the bioclastic deposits, to be analysed in thin section.

At the Vrica section (UTM coordinates: 684 654,4324 388) the contact with the substrate is well exposed. Three samples were collected from a basal rhodolithic unit and thin sections of rhodoliths were obtained from these samples. Five samples of $c .10 \mathrm{~cm}$ in size were also collected every $30 \mathrm{~cm}$ from the bottom to top of an algal build-up c. $1.5 \mathrm{~m}$ high.

Corallinales taxonomy follows the biological nomenclature, when applicable (see Woelkerling (1988) for criteria to be used in the definition of genera). Non-geniculate corallines growth forms are defined following Woelkerling et al. (1993). Form and internal structure of rhodoliths are described following Bosence (1983c) and Basso (1998). A short description of the Mediterranean benthic biocoenoses cited in the text may be found in Basso (1998).

\section{Description of basal rhodolithic unit}

The build-ups grew directly on a transgressive ravinement surface, cutting the clayey substrate. Although the contact is abrupt in most cases, both sections preserve a thin basal rhodolithic unit locally, which acted as a pavement for the settlement of the early bioconstruction. Locally, Vshaped gutters up to $15 \mathrm{~cm}$ deep infilled with rhodoliths have been found below the build-ups at the contact with the substrate (Fig. 2).

At Telegrafo section, sub-centimetric, sparse rhodoliths of Titanoderma pustulatum (Lamouroux) Nägeli were observed at the base of the coralligène framework, associated with mostly unidentified fragments of corallines, among which are Mesophyllum sp. and Amphiroa sp., abundant planktonic foraminifera, sub-millimetric fragments of bryozoans, annelids and rare molluscs in a fine matrix. The rhodoliths have a laminar, very loose internal structure, with a clayey nucleus.

At Vrica section, corallines comprise c. $90 \%$ of the biogenic sediment at the base of the coralligène framework. Some pluricentimetric mud clasts 


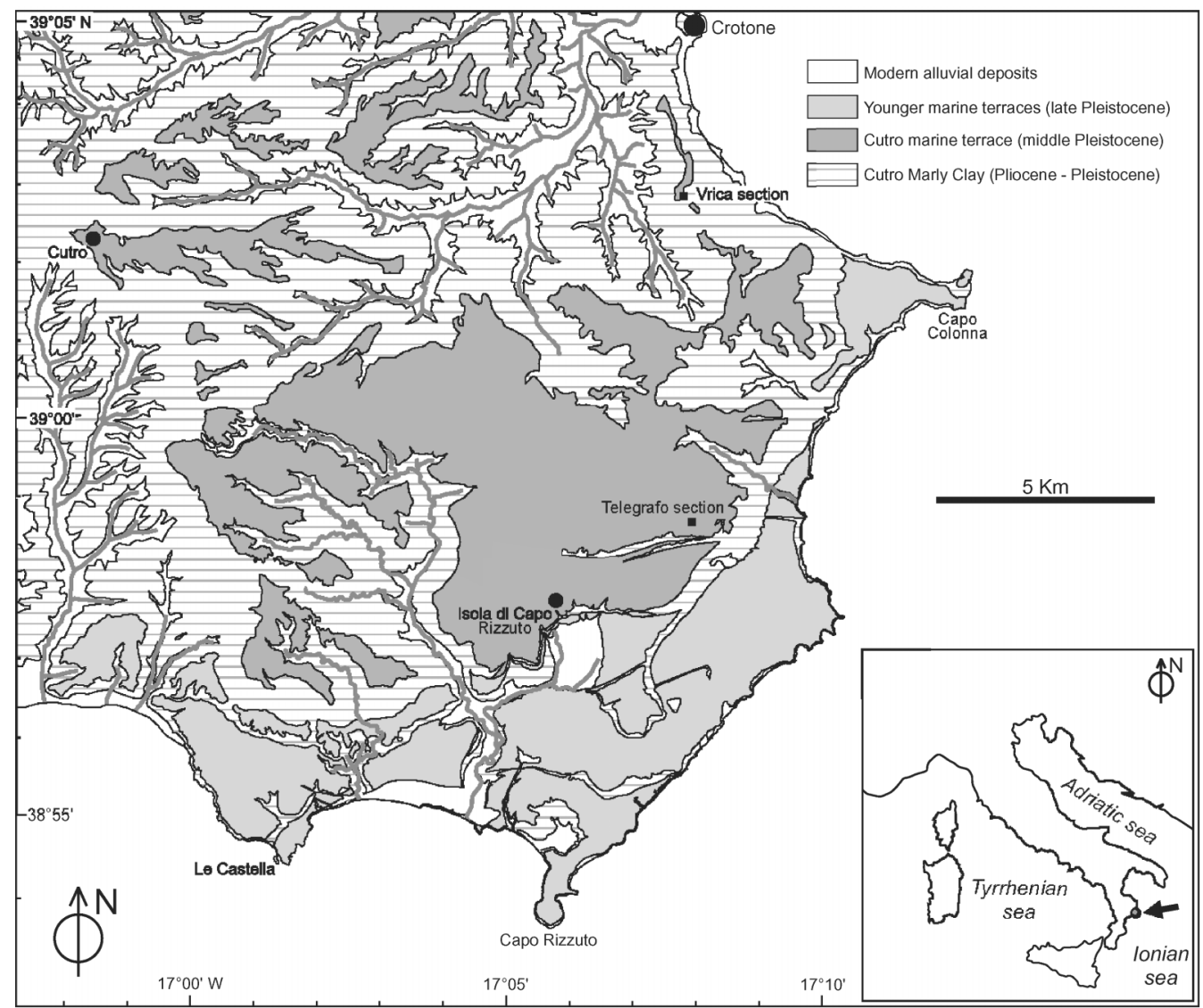

Fig. 1. Geographical location and geological sketch map of the Crotone Peninsula (after Palmentola et al. 1990 and Zecchin et al. 2004). Note wide areal extension of Cutro terrace. Inner margin of this terrace is to the NW, therefore, studied sections are located on most distal settings with respect to the palaeo-shoreline.

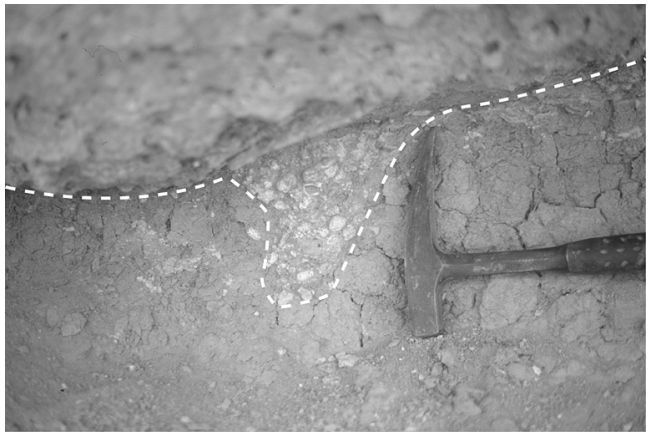

Fig. 2. Vrica section: detail of contact between clayey substrate and algal build-up. Dashed line marks gutter scoured in the substrate, infilled with rhodoliths. Head of hammer $18 \mathrm{~cm}$ long. also occur, together with a minor contribution of coarse and unworn shell fragments, rare serpulids and bryozoans. Most rhodoliths are spheroidal, with a long axis (maximum diameter) of 10$40 \mathrm{~mm}$. Well-preserved to heavily abraded rhodoliths are mixed together. The largest rhodoliths show fruticose growth form, with a cauliflower-like internal structure composed of numerous columnar protuberances, becoming confluent and platy toward the rhodolith surface (Fig. 3). A macroscopic nucleus is absent but fragments of geniculate corallines (Amphiroa sp.) and benthic foraminifers are included commonly in the algal nodules. The Vrica rhodoliths are mostly monospecific, generated by a still unidentified mastophoroid coralline and rarely by Titanoderma pustulatum. Local accumulations of broken coralline branches also occur. 


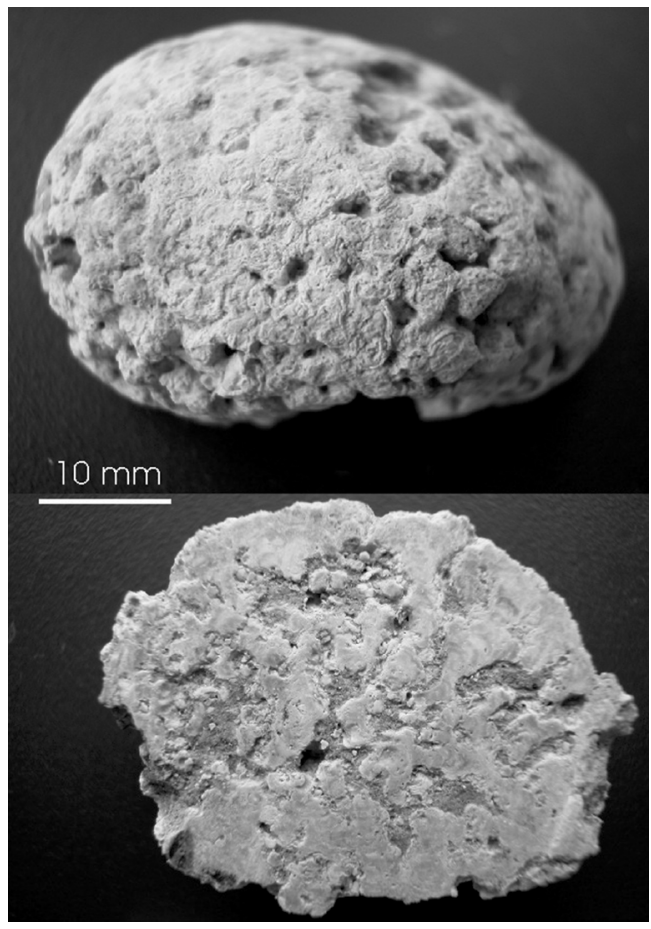

Fig. 3. External view and longitudinal section of a rhodolith taken from basal unit at Vrica section. Note abrasion of external surface and fruticose growth form of coralline algae.

\section{Description of algal build-ups}

The build-ups vary from isolated masses up to $1.5 \mathrm{~m}$ high and $3 \mathrm{~m}$ wide, to remarkably developed banks of heights up to $4.5 \mathrm{~m}$ and widths that can be tens of metres square. The first type is found prevalently in the inner and central portions of the terrace. These isolated build-ups generally present an overall ellipsoidal shape (Fig. 4) and their internal cavities have diameters of several centimetres. On the contrary, the banks, which are present only in the external area of the terrace, show a very irregular morphology, with many cavernous cavities and depressions up to $3.5 \mathrm{~m}$ deep and $6 \mathrm{~m}$ wide between prominent bioconstructed bodies, infilled with sediment (Fig. 5). Protruding ledges departing from the main mass (Fig. 5c, d) and vertically orientated algal laminae on the external surfaces of the build-ups were observed at times. This suggests that the build-ups accreted both in a lateral and vertical direction.

At Telegrafo, the most common species in the coralligène solid framework is T. pustulatum, which proves to be a major framework builder, accompanied by Mesophyllum lichenoides (Ellis)

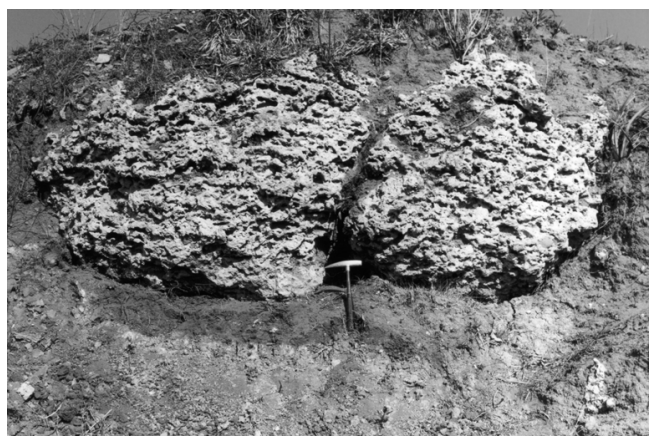

Fig. 4. View of isolated algal build-up, with overall ellipsoidal shape, lying on lower Pleistocene Cutro Marly Clay. Hammer $34 \mathrm{~cm}$ long.

Lemoine and Mesophyllum alternans (Foslie) Cabioch \& Mendoza. Lithophyllum stictaeforme (J. E. Areschoug) Hauck is never dominant, but apparently more abundant at the base of the buildups. Mastophoroids (Spongites fruticulosus Kützing and ?Neogoniolithon sp.) were also recognized. The molluscan association identified in the Telegrafo section includes the molluscs Lima lima (Linné), Haliotis tuberculata lamellosa Lamarck, Bolma rugosa (Linné), Striarca lactea (Linné), Myoforceps aristata (Dillwyn), Chlamys glabra (Linné), Chlamys multistriata (Poli), Glycymeris sp. and the brachiopod Argyrotheca sp. It is comparable with the fauna of the modern coralligène and associated biodetritic sediments. In the upper part of the section, some large specimens of the bivalve Spondylus gaederopus Linné also occur.

At Vrica, the coralligène build-up, about $1.5 \mathrm{~m}$ high, shows a dominance of $T$. pustulatum, with abundant serpulids and bryozoans. Lithophyllum stictaeforme also occurs, overgrown by $T$. pustulatum.

As observed at the Telegrafo section, other framework builders were Mesophyllum lichenoides, M. alternans, Lithophyllum stictaeforme and mastophoroids, in variable abundance. Fragments of the geniculate coralline Amphiroa cryptarthrodia Zanardini are present throughout.

\section{Description of bioclastic deposits}

Coarse- to medium-grained bioclastic deposits are found in lateral contact with the build-ups and infill their cavities (Fig. 5). Towards the top of the cavity infills, which may reach $4.5 \mathrm{~m}$, they gradually change into well-sorted medium-grained calcarenite recurrently covering the bioconstructions (Figs 5a, b). Bioclastic components are mainly 

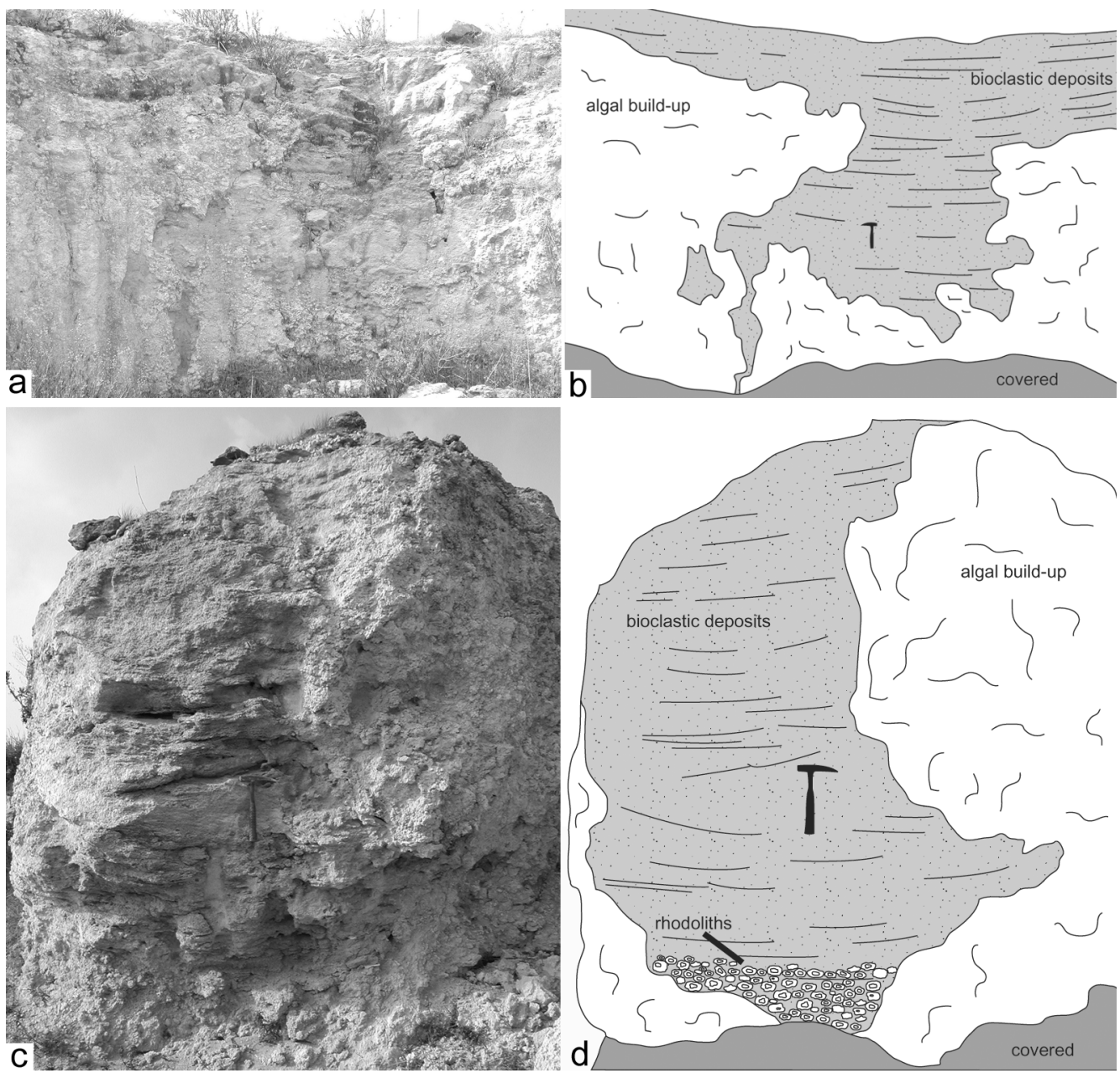

Fig. 5. Telegrafo section: views and schematic drawings of outcrops, illustrating the geometrical relationships of algal build-ups and associated bioclastic deposits. $(\mathbf{a}, \mathbf{b})$ Wide cavity between two prominent bioconstructed bodies infilled with bioclastic sediment showing traces of stratification. Overall morphology of build-up on the left is the result of equally important lateral and vertical growth; note also how the bioclastic deposits cover the build-ups. (c) d) Large cavity within algal build-up infilled with bioclastic trough cross-bedded deposits. Abraded rhodoliths are abundant in the basal portion of the infilling sediment and are shown in detail in Figure 6. Hammer for scale.

bryozoans and corallines (c. 40\% each), with $c$. $15 \%$ of molluscan fragments. Remains of serpulids, brachiopods and echinoids also occur. Whenever identification was possible, corallines and bryozoans correspond to those occurring in the solid framework. The basal $1 \mathrm{~m}$ of the deposits is characterized by the dominance of well-rounded rhodoliths, on average $2-3 \mathrm{~cm}$ in size (Fig. 6). Several rhodolithic layers are found higher in the unit, but they differ in the limited thickness (up to $4 \mathrm{~cm}$ ) and smaller size of the rhodoliths. The association of bioclasts of very different size results in poor to moderate sorting of these skeletal gravels and sands. Thin section analysis reveals also the presence of a fine micritic matrix, containing dispersed angular silt-sized quartz grains, fragments of bryozoans and corallines, molluscan larval shells, benthic and subordinate planktonic foraminifers. Another common feature is the co-existence of highly abraded allochems, such as the rhodoliths of the basal layer, and unworn delicate algal crust fragments (Fig. 7). 


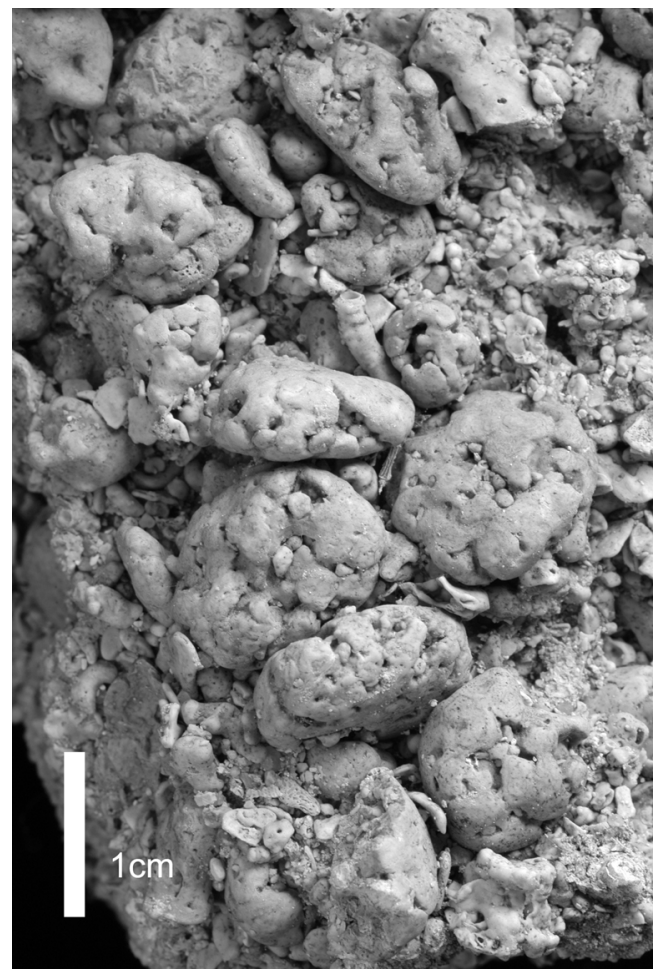

Fig. 6. Telegrafo section: detail of rhodolithic unit found within the bioclastic deposits at base of a cavity infill (see Figures $5 \mathrm{c}, \mathrm{d}$ for precise location). Note roundness due to intense abrasion and ellipsoidal shape, as well as poor sorting resulting from mixing with various skeletal elements (mainly corallines and bryozoans debris).

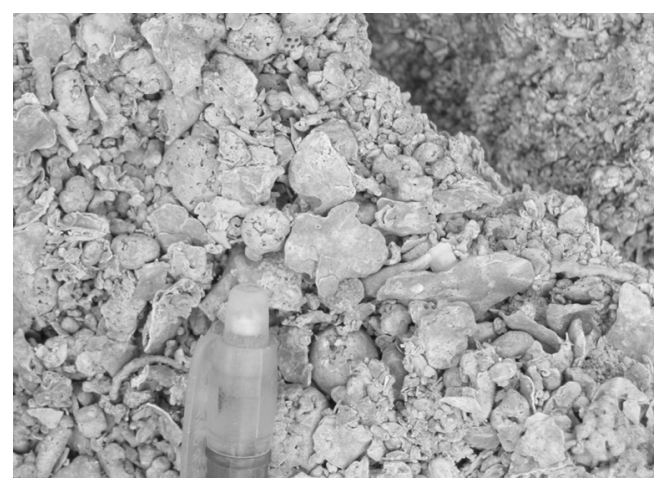

Fig. 7. Telegrafo section: well-rounded abraded rhodoliths associated with thin fragmented algal crusts within the bioclastic deposits. Pencil cap is $3 \mathrm{~cm}$ long.

The same contrasting taphonomic signal is also reflected by the common association of wellrounded siliciclastic granules with poorly elaborated bioclasts. However, a general trend of in- creasing sorting and rounding has been recognized moving towards the top of the unit, as well as a gradual increment in the siliciclastic fraction forming up to $40 \%$ of the granules. Indication of moderate activity of infaunal organisms is recorded by sparse Scolicia traces, and encrustation of mollusc shells by corallines is locally observed.

Special attention has been paid to the contact between algal build-ups and associated bioclastic deposits. Millimetric columnar algal growths and intact branched algal crusts are often found along this contact (Fig. 8), suggesting absence of significant erosion. Nevertheless, a certain degree of erosion is implied by the abundance of coralline algal fragments and by very rare cobbles of algal bioconstruction found within the associated bioclastic sediment.

Although the bioclastic deposits locally show a massive appearance, they are generally well stratified in centimetre-thick layers. In some places, individual beds are normally graded (Fig. 9). Layers preserving concentrations of isodiametric Bolma rugosa shells are also observed locally. Two main sedimentary structures can be recognized within the detrital facies. The first is a spectacular festoon-like stratification draping the inter-build-up cavities, predominantly developed in the lower to middle portion of the deposits (Fig. 10). It consists of festoon-shaped centimetre-thick laminae up to $3 \mathrm{~m}$ wide, with the concavity maximum $30 \mathrm{~cm}$ deep, in lateral contact with prominent build-ups. The second sedimentary structure, which can be found throughout the deposits, is a well-defined trough cross-stratification, with troughs up to $50 \mathrm{~cm}$ wide (Fig. 11).

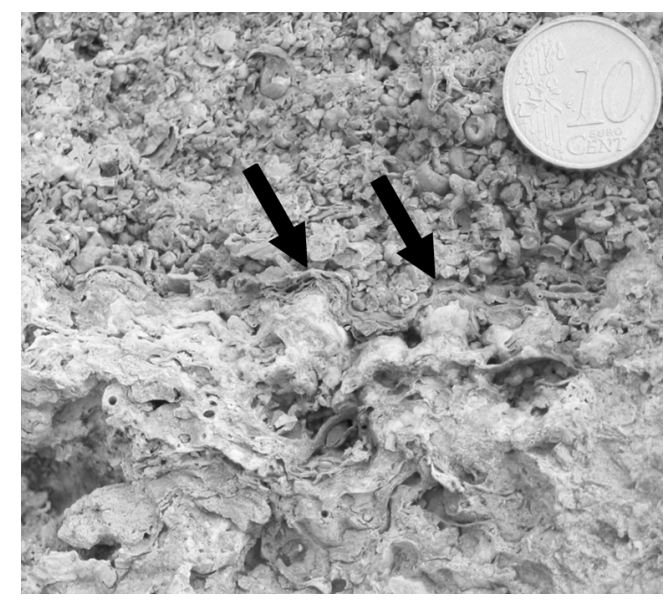

Fig. 8. Telegrafo section: detail of contact between algal build-up and associated bioclastic deposits. Arrows point to columnar algal growths preserved along this contact. Diameter of coin is $2 \mathrm{~cm}$. 


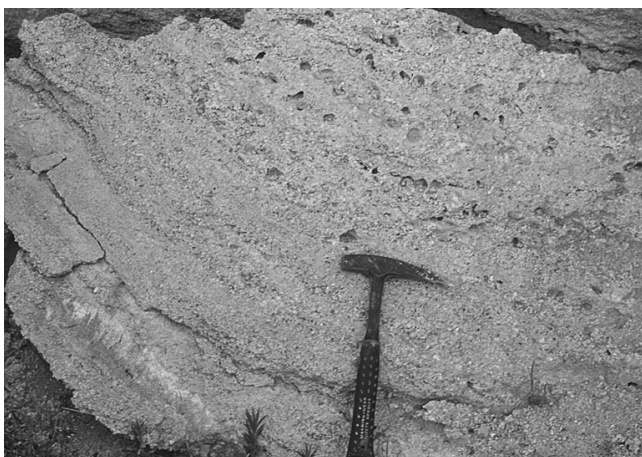

Fig. 9. Telegrafo section: normally graded layers and concentrations of hydraulically sorted Bolma rugosa shells within festoon-stratified bioclastic deposits of Figure 10.

\section{Ecological characterization of algal associations}

\section{Soft bottom: the rhodoliths}

In the modern Mediterranean, the coralline species with the widest bathymetric distribution, reaching the maximum water depth of about

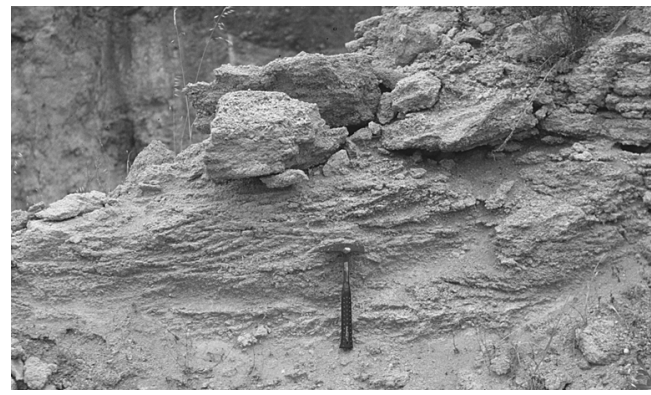

Fig. 11. Telegrafo section: trough cross-bedding within the bioclastic deposits. Hammer for scale.

$90 \mathrm{~m}$ in the western Mediterranean, is Titanoderma spp. In contrast, a diversified coralline association normally occurs in rhodoliths at $40-60 \mathrm{~m}$ of water depth. The internal structure, growth form and species comprising deep rhodoliths have been schematized by Basso (1998) into three major groups: (1) free-living branches, monospecific; (2) prâlines, compact, mono- or oligospecific rhodoliths; and (3) boxwork rhodoliths (sensu Bosence 1983c), normally multispecific, loose internal structure with cavities infilled by sediment. They characterize the circalittoral (corresponding to the lower sublittoral of Hedg-

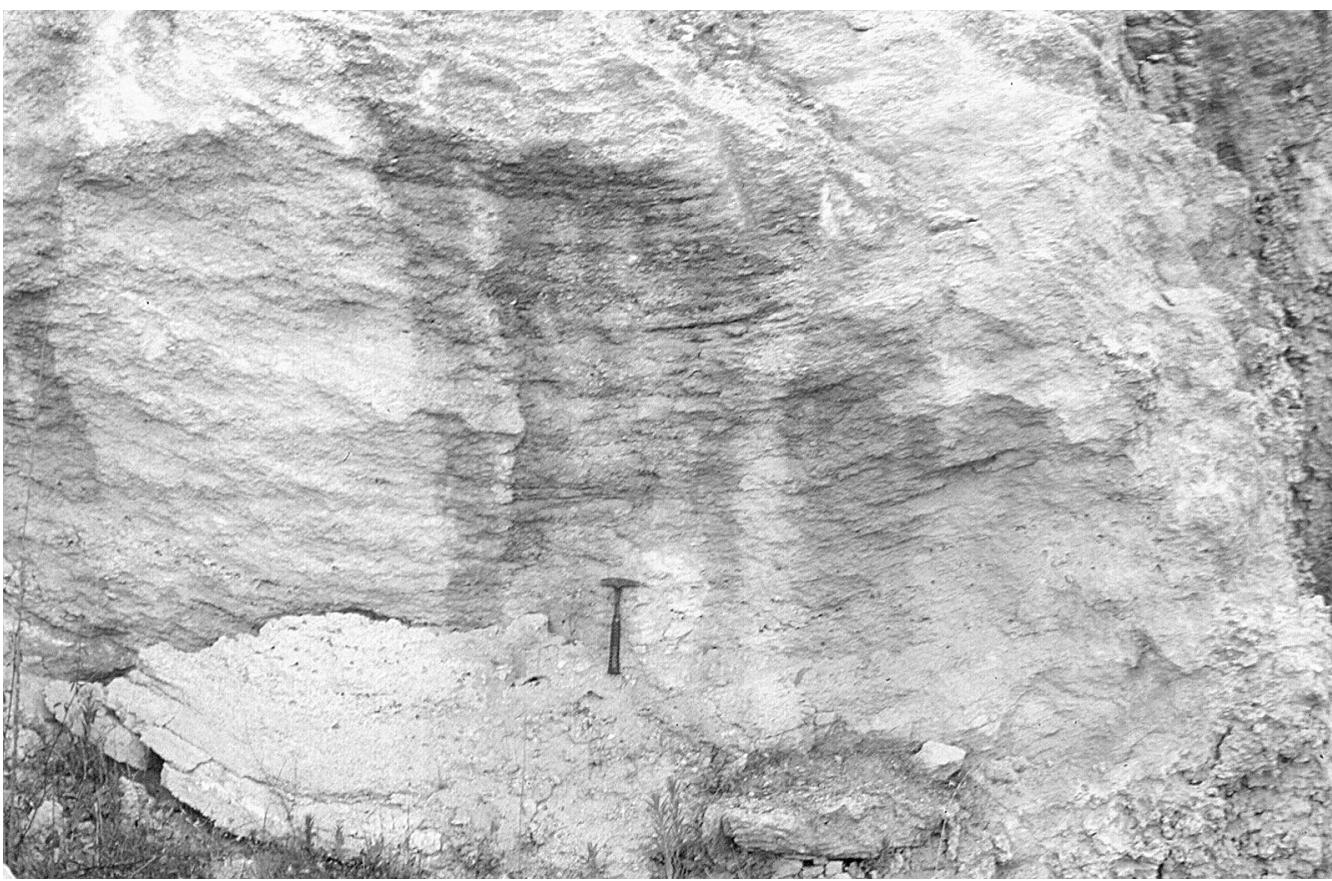

Fig. 10. Telegrafo section: large festooned stratification within bioclastic deposits infilling a wide cavity between algal build-ups. Close up of this structure is shown in Figure 9. Hammer for scale. 
peth 1957) benthic environments with soft substrates that can be described on the basis of different combinations of water energy (bottom currents and/or storm waves) and sedimentation rate (Basso 1998). Following the Mediterranean benthic bionomy (Pérès \& Picard 1964; Pérès 1982) these environments span from the biocoenosis of Sands and Gravels under bottom currents (SGCF) to the coralligène de plateau (C) through the several facies of the Coastal Detritic biocoenosis (DC). Fruticose rhodoliths growing under the strongest water energy (SGCF) show a distinct morphology, with protuberances enlarging toward the tips, where they coalesce to create an apparently flat external surface. The constant abrasion of the thallus surface at the tip of protuberances due to frequent rolling on the coarse sediment is responsible for this cauliflower-like internal structure, which is interpreted as an adaptive strategy to mechanical disturbance, leading different coralline species to a morphological convergence (Steneck 1986; Basso 1996).

Rhodoliths at the base of Telegrafo section are small, with a loose internal structure and composed of Titanoderma sp. In contrast, rhodoliths at the base of Vrica section are cauliflower-like, compact and monospecific. Therefore, on the basis of shape, internal structure, species composition and accompanying microfacies, a comparatively deeper and quieter palaeoenvironment is suggested for the Telegrafo rhodoliths (lower circalittoral zone) than for the Vrica rhodoliths (upper circalittoral).

\section{Hard bottom: the coralligène}

Crustose, relatively fast-expanding algal thalli are the best adapted to compete for space on a hard bottom. Actually, the crustose Mesophyllum lichenoides, Titanoderma pustulatum and Lithophyllum stictaeforme ( $=$ L. grandiusculum, $=$ L. cabiochae) are major framework builders, since they are able to form crustose, more or less laminar protuberances creating bridges between the plant and neighbouring substrate to be occupied. This peculiarity also allows the early stabilization of the rhodoliths and the creation of the first hard substrate on which the framework can develop. The constant competition for space with other hard bottom dwellers such as bryozoans, annelids, and sessile molluscs, and the frequent superposition of different organisms lead to the formation of the characteristically porous structure of the coralligène. The algal association of the solid framework, though rather monotonous in species composition, shows the best development of algal thalli toward the top of the build-ups.
According to Sartoretto et al. (1996) the accretion rate in present-day Mediterranean coralligène is very low or non-existent below $50 \mathrm{~m}$; conversely, the maximum growth rate is recorded between $10 \mathrm{~m}$ and $35 \mathrm{~m}$ depth (Sartoretto et al. 1996). The coralline species responsible for most of the biogenic solid structure of the Crotone Pleistocene coralligène are consistent with those identified in the modern Mediterranean rocky shore coralligène, including the ubiquitous occurrence of Amphiroa cryptarthrodia fragments (Sartoretto et al. 1996). Among the major framework builders, it appears that, at present, Mesophyllum is dominant in the shallowest coralligène (about 10-20 m), while Lithophyllum dominates below $20 \mathrm{~m}$ (Sartoretto et al. 1996).

\section{Discussion}

Both studied sections illustrate how the first growth stage of coralligène de plateau is the stabilization of a very coarse biogenic detritus of the rhodalgal type (Carannante et al. 1988), due to the binding action of non-geniculate corallines overgrowing each other.

The bioclastic deposits accumulated synchronously with the growth of the adjacent algal banks, with the exception of the upper portion covering the build-ups. This is substantiated by the high percentage of algal detritus within the deposits, which is compositionally equivalent to the flora and fauna of the build-ups and is preserved in fresh taphonomical conditions. The build-ups were therefore a major source of carbonate particles, under the combined action of physical and biological erosion. However, in spite of the coeval development of build-ups and bioclastic sediments, these two facies rarely present erosional contacts. Instead, it is more common to find algal crusts encroaching over the bioclastic deposits. This progressive growth resulted in prominent bioconstructed bodies displaying laterally overhanging ledges in places, but original average elevation above the surrounding sea bottom is difficult to estimate. Data on modern coralligène show variations in relief from 10$30 \mathrm{~cm}$ (Bosence 1983a, b) to 1-4 m (Laborel 1961; Sarà 1967; Bosence 1985; Toscano \& Sorgente 2002), which suggests that an irregular seafloor morphology existed also during the formation of the Cutro terrace algal banks.

Intermittent sedimentation from storm-driven currents alternating with phases of low hydrodynamic regime seems to explain the observed sedimentological features of the studied units better. Low sedimentation rates, low hydrodynamic energy and weak luminosity are known to be important abiotic factors for the development of 
coralligène de plateau (Laborel 1961, 1987; Pérès 1982; Carannante et al. 1988). Therefore, Cutro terrace build-ups extensively grew below fairweather wave base, where the background sedimentation was given by deposition from suspension. Fine-grained sediment is, in fact, found within the bioclastic deposits and is trapped in the interstitial spaces of the crustose algal framework. Calm water conditions favoured encrustation of skeletal elements, bioturbation of detrital gravels and sands by echinoids and predominance of open leafy frameworks within the build-ups. On the other hand, recurrence of moderate to high-energy events is recorded by the sedimentary structures of the bioclastic deposits. Storm-induced currents may have had enough competence to generate trough cross-bedding and normally graded layers, especially if the flows were channelled by lateral confinement due to the relief of the build-ups. The observed festoon-like stratification is considered as a secondary structure instead, originating from differential compaction of the porous unconsolidated bioclastic sands and gravels with respect to the adjacent bioconstructions. Material transported from shallower higher-energy settings during storm events, mixed with the autochthonous carbonate production, generated a distinctive rounding bimodality, with co-existence of well-rounded and abraded particles and poorly reworked allochems.

A clear shallowing-upward trend is indicated both by the build-ups and the bioclastic deposits. Changes in framework morphology and ecological association of the crustose coralline algae within the bioconstructions are echoed by changes within the bioclastic deposits towards better sorted and rounded high-energy facies (Fig. 12), containing a significant fraction of siliciclastic grains. This gradual transition culminates with the burial of the build-ups by well-sorted bioclastic sands, interpreted as shoreface deposits.

\section{Sequence-stratigraphic model}

A simple sequence-stratigraphic model enables framing of the temporal evolution of the coralligène de plateau and associated deposits of Cutro marine terrace in the context of a single transgressive-regressive cycle. Three distinct phases have been identified (Fig. 13).

1. TST: a ravinement surface is created by shoreface retreat during transgression. A thin basal transgressive lag, consisting of siliciclastic pebbles, reworked mud-clasts, bioclasts and abundant rhodoliths, acts as substrate colonized by crustose coralline algae, which give rise to a solid framework. Spaces between these incipient build-ups

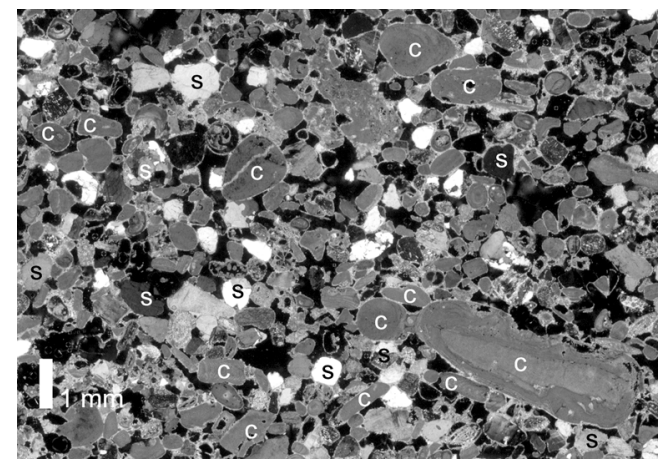

Fig. 12. Telegrafo section: thin section of sample taken from uppermost interval of bioclastic unit. Note good sorting and rounding of granules. Abraded particles of coralline algal debris (labelled 'c') may preserve an elongated shape and have larger size. Siliciclastic grains ('s') are well represented. Viewed in cross-polarized light.

with moderate relief are infilled partly with abraded rhodoliths transported from shallower settings during storm events.

2. HST: maximum development of algal buildups. Areas between individual bioconstructions are affected by intermittent sedimentation from storm-driven currents, as shown by traces of cross-stratification. Sparse Scolicia burrows, locally truncated by storm-related erosional surfaces, document the intermittence of high-energy events. Storm-driven flows commonly lead to mixing of locally produced coralline algal detritus with granules transported from inner shallower settings.

3. Falling-stage systems tract (FSST): changes in framework fabric and ecological association within the build-ups, as well as better sorting and an increase in silicilastic component within the bioclastic deposits, are consistent with a shallowing trend. The bioconstructions are eventually buried by calcarenite shoreface deposits of the regressive phase, which gradationally overlie the bioclastic sands and gravels infilling the spaces between the build-ups. No evidence of a regressive surface of marine erosion was found in the studied sections. However, other localities in the more internal portion of the terrace show abrupt erosive contacts between the build-ups and upper shoreface deposits, providing evidence of forced regression.

\section{Conclusions}

Valuable insights into the genesis and development of coralligène de plateau and associated 

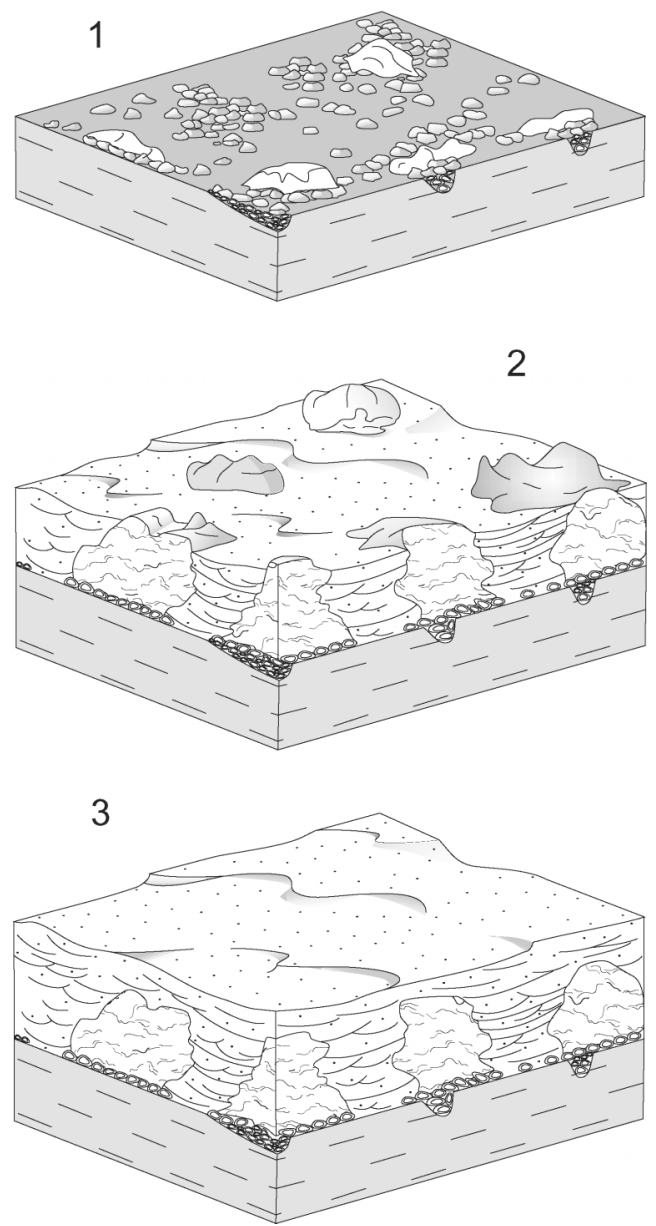

Fig. 13. Stages of development of coralligène de plateau and associated bioclastic deposits. See text for discussion.

bioclastic deposits have been gained from the study of Pleistocene outcrops in the sedimentary cover of Cutro marine terrace.

1. Algal build-ups, composed primarily of Titanoderma pustulatum, Mesophyllum alternans and M. lichenoides, grew between fair-weather wave base and storm wave base at depths between $30 \mathrm{~m}$ and $60 \mathrm{~m}$ (Henrich et al. 1995; Carannante \& Simone 1996; Sartoretto et al. 1996). They occur as isolated masses of limited extent but also as remarkably developed banks, covering tens of square metres of sea bottom. Their preserved maximum thickness does not exceed $4.5 \mathrm{~m}$ and their morphology is very cavernous, with many large cavities and areas several metres wide between prominent bodies infilled with sediments. A thin unit up to $10 \mathrm{~cm}$ thick, consisting predominantly of rhodoliths, is commonly found at the base of the algal bioconstructions. This indicates that the first stage of coralligène settlement is the stabilization of a loose rhodolithic pavement through the binding action of coralline algal crusts. On the basis of thalli development and species associations and dominance, the early formation of coralligène on the rhodoliths is interpreted to be triggered by conditions of sediment starvation, slackening of water energy and weak luminosity induced by deepening of the palaeobiotope. During their growth, the build-ups maintained a discrete relief above the surrounding seafloor and represented a local source of carbonate detritus under the action of physical and biological erosion. The intervening phase of regression allowed the algal association to flourish towards the top of the build-ups, as observed particularly at Telegrafo section. Thus, the highest growth rate and probably the maximum relief of the build-ups occurred during the early stage of regression, before their final burial.

2. Bioclastic deposits, varying from rudstones to grainstones and packstones, are found in lateral contact with the build-ups. They may be considered rhodalgal-type carbonates (Carannante et al. 1988), consisting of rhodoliths, coralline algal crusts and debris, bryozoans and echinoids fragments, molluscs shells and fragments. Their composition and taphonomic signature indicate an autochthonous and parautochthonous provenance, with part of the sediment transported from shallower settings during high-energy events. Observed sedimentary structures indicate phases of sedimentation from storm-driven currents alternating with phases of calm-water conditions. This scenario seems to solve the apparent paradox of the co-existence of coralligène de plateau - which requires low to moderate energy for its growth (Basso 1998; Rasser \& Piller 2004) - with deposits indicating an active hydrodynamic regime. Although these two facies developed at the same time, the overall sedimentation rate of the bioclastic limestone should have been low; otherwise, the build-ups would have been covered and their growth prevented. The studied units were deposited during a single stratigraphic cycle. This cycle began with generation of a ravinement surface during transgression and ended with burial of the 
coralligène by shoreface calcarenites. Sedimentological features of the bioclastic deposits, gradually passing into the uppermost calcarenite, clearly document a shallowingupward trend. Such a trend is also mirrored by variations in framework morphology and ecological association of the crustose coralline algae within the build-ups.

The authors are indebted to A. D'Alessandro for valuable discussion in the field. N. Michelon kindly drew Figure 13. Reviews by J. J. Fornós and A. Photiodes are gratefully acknowledged. This research was funded by a MURST(ex40\%) grant for the project 'Cyclic sedimentation and Climatic Variability in the Italian Quaternary', co-ordinated by F. Massari.

\section{References}

BAsso, D. 1996. Adaptive strategies and convergent morphologies in some Mediterranean coralline algae. In: Cherchi, A. (ed.) Autoecology of selected fossil organisms: achievements and problems. Bollettino della Società Paleontologica Italiana, Special Volume, 3, 1-8.

BAsso, D. 1998. Deep rhodolith distribution in the Pontian Islands. Italy: a model for the paleoecology of a temperate sea. Palaeogeography, Palaeoclimatology, Palaeoecology, 137, 173-187.

Bosence, D.W.J. 1983a. Coralline algae from the Miocene of Malta. Palaeontology, 26/1, 147-173.

Bosence, D.W.J. 1983b. Coralline algal reef framework. Journal of the Geological Society, London, 140, 365-376.

Bosence, D.W.J. 1983c. Description and classification of rhodoliths (rhodoids, rhodolites). In: PERYT, T.M. (ed.) Coated Grains. Springer-Verlag, Berlin, 217-224.

Bosence, D.W.J. 1985. The "coralligène" of the Mediterranean - a recent analog for Tertiary coralline algal limestones. In: Toomey, D.F. \& NitecKI, M.H. (eds) Palaeoalgology: contemporary research and applications. Springer-Verlag, Berlin, 216-225.

Bosence, D.W.J. \& Pedley, H.M. 1982. Sedimentology and palaeoecology of a Miocene coralline algal biostrome from the Maltese Islands. Palaeogeography, Palaeoclimatology, Palaeoecology, 38, 9-43.

Carannante, G. \& Simone, L. 1996. Rhodolith facies in the Central-Southern Apennines Mountains, Italy. In: Franseen, E.K., Esteban, M., Ward, W.C. \& Rouchy, J.-M. (eds) Models for Carbonate Stratigraphy from Miocene Reef Complexes of Mediterranean Regions. Society for Sedimentary Geology, Concepts in Sedimentology and Paleontology, 5, 261-275.

Carannante, G., Esteban, M., Milliman, J.D. \& Simone, L. 1988. Carbonate lithofacies as paleolatitude indicators: problems and limitations. Sedimentary Geology, 60, 333-346.

GliozzI, E. 1987. I terrazzi del Pleistocene superiore della penisola di Crotone (Calabria). Geologica Romana, 26, 17-79.

HedgPeth, J.W. 1957. Classification of marine environ- ments. In: Hedgreth, J.W. (ed.) Treatise on marine ecology and paleoecology. Geological Society of America Memoirs, 67, 17-28.

Henrich, R., Freiwald, A. \& Betzler, C. 1995. Controls on modern carbonate sedimentation on warm-temperate to arctic coasts, shelves and seamounts in the Northern Hemisphere: implications for fossil counterparts. Facies, 32, 71-108.

JAMES, N.P. 1997. The cool-water carbonate depositional realm. In: JAMES, N.P. \& Clarke, A.D. (eds) CoolWater Carbonates. Society for Sedimentary Geology, Special Publications, 56, 1-20.

LABOREL, J. 1961. Le concrétionnement algal 'coralligène' et son importance geomorphologique en Méditerranée. Recueil des Travaux Station Marine d'Endoume, 23, 37-60.

LABOREL, J. 1987. Marine biogenic constructions in the Mediterranean - A review. Scientific reports of the Port-Cros National Park, 13, 97-126.

Massari, F., Rio, D. \& Sgavetti, M. 2002. Interplay between tectonics and glacio-eustasy: Pleistocene succession of the Crotone basin, Calabria (southern Italy). Geological Society of America Bulletin, 114/ 10, 1183-1209.

Nelson, C.S., Freiwald, A., Titschack, J. \& List, S. 2001. Lithostratigraphy and sequence architecture of temperate mixed silicilastic-carbonate facies in a new Plio-Pleistocene section at Plimiri, Rhodes Island (Greece). Department of Earth Sciences, University of Waikato, New Zealand, Occasional Report, 25.

Palmentola, G., Carobene, L., Mastronuzzi, G. \& SAnsò, P. 1990. I terrazzi marini Pleistocenici della Penisola di Crotone (Calabria). Geografia Fisica $e$ Dinamica Quaternaria, 13, 75-80.

PÉrès, J.M. 1967. The Mediterranean benthos. Oceanography and Marine Biology Annual Review, 5, 449-533.

PÉRÈs, J.M. 1982. Major benthic assemblages. In: Kinne, O. (ed.) Marine Ecology. John Wiley \& Sons Ltd, Chichester, 5/1, 373-522.

PÉrès, J.M. \& PICARD, J. 1964. Nouveau manuel de Bionomie benthique de la Mer Méditerranée. Recueil des Travaux Station Marine d'Endoume, 31/ 47, 1-137.

RAsSER, M.W. 2000. Coralline red algal limestones of the Late Eocene alpine foreland basin in upper Austria: component analysis, facies and palecology. Facies, 42, 59-92.

Rasser, M.W. \& Piller, W.E. 2004. Crustose algal frameworks from the Eocene Alpine Foreland. Palaeogeography, Palaeoclimatology, Palaeoecology, 206, 21-39.

RodA, C. 1964. Distribuzione e facies dei sedimenti Neogenici nel Bacino Crotonese. Geologica Romana, 3, 319-366.

Sartoretto, S., Verlaque, M. \& Laborel, J. 1996. Age of settlement and accumulation rate of submarine 'coralligène' $(-10$ to $-60 \mathrm{~m})$ of the northwestern Mediterranean Sea; relation to Holocene rise in sea level. Marine Geology, 130, 317-331.

SARÀ, G. 1967. Un coralligeno di piattaforma (coralligène de plateau) lungo il litorale pugliese. Archivio di Oceanografia e Limonologia, 15, 139-150. 
Steneck, R.S. 1986. The ecology of coralline algal crusts: convergent patterns and adaptive strategies. Annual Review of Ecology and Systematics, 17, 272-303.

Toscano, F. \& Sorgente, B. 2002. Rhodalgal-bryomol temperate carbonates from the Apulian Shelf (Southeastern Italy), relict and modern deposits on a current dominated shelf. Facies, 46, 103-118.

WoelKerling, W.J. 1988. The coralline red algae: an analysis of the genera and subfamilies of non geniculate Corallinaceae. British Museum (Natural
History), London and Oxford University Press, Oxford.

Woelkerling, W.J., Irvine, L.M. \& Harvey, A.S. 1993. Growth-forms in non-geniculate coralline red algae (Corallinales, Rhodophyta). Australian Systematic Botany, 6, 277-293.

Zecchin, M., Nalin, R. \& Roda, C. 2004. Raised Pleistocene marine terraces of the Crotone peninsula (Calabria, Southern Italy): facies analysis and organization of their deposits. Sedimentary Geology, 172, 165-185. 